\title{
Female Indigenous entrepreneurship in remote communities in northern Australia
}

\author{
${ }^{*}$ Cecil A. L. Pearson ${ }^{1}$, Sandra Daff ${ }^{2}$ \\ ${ }^{1}$ School of Management, Curtin University, Perth, Western Australia \\ ${ }^{2}$ Porcupine, Queensland, Australia \\ ${ }^{*}$ Cecil.Pearson@cbs.curtin.edu.au
}

\begin{abstract}
Little is known about Australian Indigenous female entrepreneurship. Misconceptions typifying Australian Indigenous businesses are community enterprises are encumbered by research limitations, generalisations and stereotyping; the material is seldom voiced by Australian Indigenous people; and few sources detail the challenges for grass roots female Indigenous entrepreneurs in remote Australian Aboriginal communities that maintain patriarchal cultures. In this paper is described how 21 Indigenous female entrepreneurs in a remote region of northern Australia have tailored their businesses to comply with the regulatory and statutory framework of the dominant society while preserving sensitivity to the traditional cultural norms, rules, and obligations. The data were independently corroborated by Indigenous and non Indigenous men of recognised standing in the region. These empirical observations provide foundation for better informed judgements about the business environment in remote regions of Australia, which is fundamental when developing policies for delivering sustainable female Indigenous small businesses.
\end{abstract}

Keywords: Entrepreneurship, female Indigenous Australians, remote regions

\section{Introduction}

During the past 15 years Australian Indigenous female entrepreneurship has disturbingly attracted scant momentum. The relatively low traction is disquieting given the recognised importance of entrepreneurship in the Australian marketing economy (Minifie, 2014; Wood, 2011), the continuing voiced commitment of the Australian Commonwealth Government to develop Indigenous business programmes (Australian Government, 2007; 2010; IOP, 2011), the championing of successive Organisation for Economic Cooperation Development (OECD) contributions (1998; 2001; 2012) to raise the profile of economic activities of female minorities in Australia, and a limited body of literature dealing with Indigenous women in family business (AWCCI, 2012; McDonnell, 1999; Sonfield \& Lussier, 2009). Overall, Australian women's Indigenous entrepreneurship is imprudently presented without gender disaggregated statistics, and, consequently, little is known about Australian female Aboriginal entrepreneurs. Female Indigenous entrepreneurship lacks resonance within the propensity of Australian small business. In spite of the growing geographic and sector spread of Australian Indigenous micro enterprises the Indigenous participation in the Australian mainstream economy is relatively low (Australian Government, 2009; Foley, 2006; Furneaux \& Brown, 2008), the ratio of Australian Indigenous to non Indigenous self employment is about 0.3 (Hunter, 2012), and a lack of gender aggregation shows the field of study about female Indigenous owned business remains under developed. With few exceptions much of the literature reports Australian Indigenous entrepreneurial activity in the more popular and research accessible sites to review "... the vastly different experiences of the Indigenous Australian compared to their non -indigenous counterparts” (Wood \& Davidson, 2011:312).

Comparatively, remote communities are likely to experience a different range of challenges to suburban Indigenous enterprises, and these features have realised a variety of problematic assumptions (i.e., cultural attitudes, hunter gatherer interests) for the low participation rate of Australian Aboriginal entrepreneurial activity (Abbott, 2002; Cook \& Monypenny, 2012). Moreover, research embedded in mainstream Western economic paradigms espousing a profitable outcome for the principal protagonist (Hindle \& Moroz, 2009; Kukoc\& Regan, 2008) is potentially meaningful in city/suburban contexts, but is unlikely to be embraced in remote Indigenous communities engaged in a fundamentally different customary economy to the dominant Australian culture (Altman, 2002). In these rural regions personal networking and community norms facilitate dimension of reciprocity and trust (Foley, 2006; Kilpatrick, Field \& Falk, 2003) to build hybrid models (Jones, 2007; Pearson \& Helms, 2012; 2013) hastening collaborative and cooperative endeavours to resolve problems in the pursuit of the common good (Peredo \& Chrisman, 2006; Yunus, 2006). A disparate range of lines of enquiry has not yet led to the 
establishment of a taxonomy of Australian Indigenous entrepreneurship in general or the specific understanding of the dominant values unifying Aboriginal women entrepreneurs.

Within the Australian Indigenous entrepreneurship literature there are growing celebrations of female achievements. This paper builds on these contributions (Pearce, 2011) in five parts after the Introduction. In the first part is provided an overview of the rich tapestry of Indigenous entrepreneurship endeavours in the remote east Arnhem Land of the Northern Territory (NT) of Australia to provide a point of departure for focussing on contemporary female Indigenous entrepreneurship in an isolated Greenfield region. Places of interest that are mentioned in the paper are shown on a map that is presented as Figure 1. The second part of the paper, the Methodology, partitions the relevant information to describe how the respondents were chosen, the sites of their businesses, how the data were obtained, and the processes of assessment. In the third part of the paper the findings are reported in text and succinctly summarised with two Tables. The Discussion is the fourth part of the paper where connections with the extant literature are presented. A Conclusion, the fifth part, provides information that may appeal to the vigilance of those who have, or are likely to have, a pecuniary stake in Australian Indigenous entrepreneurship.

Figure 1: Points of interest in the study area

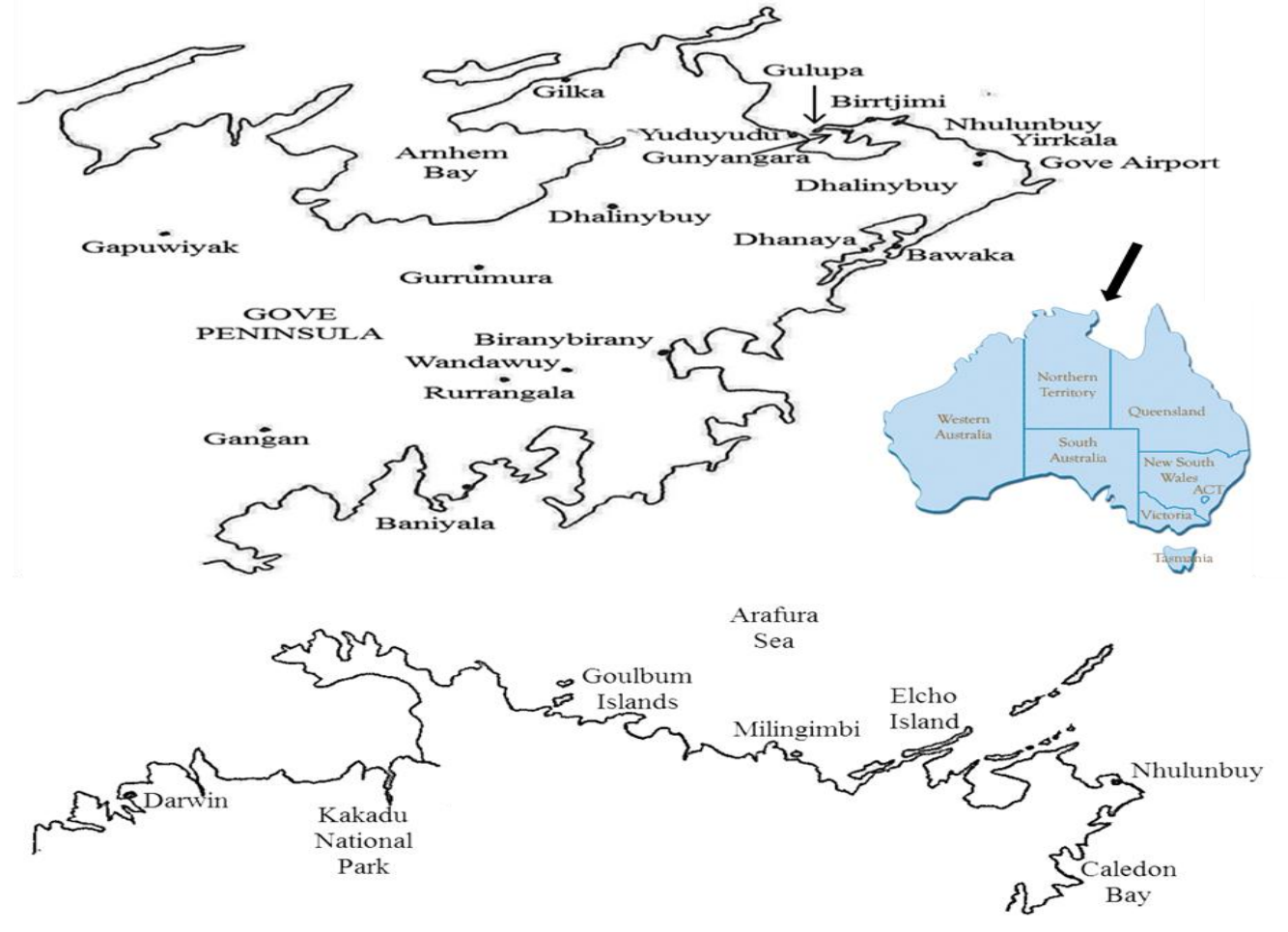

Purpose of This Study: The scant Australian Indigenous female small business literature is mainly founded on observations in urban and more populated regions. Australian Indigenous micro business is treated as a homogenous sector allowing operational frameworks of the businesses to be compared with Western tenets of entrepreneurship (AWCCI, 2012; Furneaux \& Brown, 2008; Wood \& Davidson, 2011). Consequently, these endeavours have led to postulations Indigenous small business Australia is mainly undertaken by men, the operators want to become financially independent, or it is undertaken to escape poverty. These parameters are unlikely to resonate with Indigenous Australian communities residing on ancestral lands and existing in communal traditional lifestyles. Indeed, much has been written about contemporary Australian Indigenous small communities engaging in hybrid social economies, beyond the national marketplace (Altman, 2002; Pearson, Daff \& Helms, 2014; Suter, 2003). A scarce availability of reliable and valid data continues to be a salient barrier to understand Australian Indigenous female entrepreneurship, which warrants gender disaggregation of Australian Indigenous small business. Exploring the challenges and contributions of Australian Indigenous women entrepreneurs in a secluded region, free from cosmopolitan contextual influences, is the focus of this paper. 
The purpose of this study is twofold. First, is to obtain empirical evidence about Aboriginal entrepreneurial activities on the Gove Peninsula in terms of how and why Indigenous females in the region engage in small business. Second, to ascertain the barriers Indigenous women face when endeavouring to develop their business in this remote region of Australia. Findings to these two lines of enquiry have implications for existing theories of entrepreneurship and have lessons for bridging the gender inequality in entrepreneurship, particularly in less developed countries “... where women are restricted by patriarchal systems and social barriers...” (Sarfaraz \& Faghih, 2011: 47). It is well established Indigenous Australians are over represented among the nation's most disadvantaged citizens, and important components of the observations of this study have potential for relevant Australian government representatives to undertake informed judgements to develop the practical and sustainable installation of Indigenous female entrepreneurship in remote regions of the nation as a strategy to reduce socio economic disadvantage.

\section{Indigenous Entrepreneurship on the Gove Peninsula}

Sharing the experiences of Australian Indigenous micro enterprises is intensifying, disparately. More recent Australian government policy (Australian Government, 2010) encourages the adoption of earlier federal government investigations, and programmes designed to create opportunities for Indigenous small business (Australian Government, 2007; 2009; 2010). Accompanying this documentation is a range of published work from a variety of authors revealing a host of geographically dispersed Australian small businesses endeavours (Cape York, 2005; Foley, 2006; Russell-Mundine, 2007). While formulating a theoretical and empirical informed typology about Australian Indigenous entrepreneurial activities to suit all circumstances is laudable the divergence in "... economic, cultural, natural, technological and political environments" (Choi \&Sirakaya, 2006:1277) repositions a genuine commitment to attain greater understanding and articulation of differences between urban, rural and remote locations (Whitford \& Ruhanen, 2010). Evidence provided by Dana (1995) revealing Indigenous people responded differently to opportunity supports the notion the development of flexible frameworks for investigating small business activities undertaken to address complex local problems of remote Australian Aboriginal communities might be better facilitated by examining a discrete region. Hence, this paper is based on a historical overview of Indigenous entrepreneurship in east Arnhem Land of the NT of Australia where business activity has been embedded in the livelihood of the community.

Beginnings of Indigenous Contemporary Entrepreneurship: The earliest Australians were Indigenous entrepreneurs, who laboured for the survival of the clan. Anthropologists and historians contend the northern regions of the Australian continent were inhabited some 50,000 years ago via a land bridge (Muir, 2011;Suter, 2003), and in spite of basic technology and limited innovation with social involvement groups were able to argument a permanent community with security from other clans (Johns, 2011). Worsley (1955) claims the forebears of the contemporary east Arnhem Land Yolngupeople established some form of subsistence activity, mainly hunting and fishing, “... long before any other Australian aboriginal group. " (p.3). There is some evidence clan members undertook rudimentary seasonal horticultural activities that featured as the gathering of yams, nuts, honey and fruits, and even the weaving of the pandanuspalm for carrying utensils in the pursuit of sustaining the community. Despite limited technical equipment, hampered by a hostile environment, and the likelihood settlement would be restricted to coastal regions reference has been made of economic activities and bartering between the Arnhem Land Aborigines (Ivory, 1999; Rose, 1987).

Written records show Arnhem Land Aboriginal people have traded with seafarers since the $17^{\text {th }}$ century. Following encounters with early European sailors (WillemJanszoonDuyfken,1605; WilliemJoosten van Colster, Arnheim, 1623), more frequent reference is made of the interactions of the Aboriginal people of the NT and the fishermen from Macassar of Southern Sulawesi (Macknight, 1972; Russell, 2004; Searcy, 1909). These seamen made annual visits to the northern coast of Australia from the 1700s until 1907 when the fishing licenses were cancelled by the South Australian government, which at that time administered the NT. Confirmatory evidence of the extensive trade between the Yolngu people and the Macassans for pearls, turtle shell, fish and trepan, that were exchanged for steel (spear heads), axes, cloth, tobacco and alcohol, is described in a variety of sources (Berndt \& Berndt, 1999; Macknight, 1976; Trudgen, 2000; Worsley, 1955). With suggestion the Yolngu trade with northern neighbours stimulated inter tribal entrepreneurship. 
Establishing Methodist missions in Arnhem Land has provided a bedrock for Yolngu people within 200 $\mathrm{km}$ of Yirrkala to pathway into small business endeavours. Missions were established on South Goulburn Island in 1916, followed by Elcho Island in 1922 (later relocated to Miligimbi in 1924, and then back to Elcho Island in 1942), and at Yirrkala in 1935 (Shepherdson, 1981). Bringing sustenance, religion, health and education to the Indigenous people, who left their distant homelands and congregated at these mission stations, compelled the installation of work practices to ensure food production, distribution, and surplus storage as well as the learning of a wide range of appropriate job skills and the adoption of work schedules. These arrangements had not been encountered in the engrained habits of the local Aboriginal lifestyles. Large numbers of Indigenous men were employed at the Milingimbi and Elcho Island missions to harvest and mill cypress pine to build dwellings and buildings while Indigenous women worked in the constructed hospitals and schools (McKenzie, 1976; Shepherdson, 1981). The acquired business acumen became opportunistic for creating small business endeavours when the mining industry came to the Gove Peninsula in the 1960s, but within a decade social forces decimated the Yirrkala community. Nevertheless, by the mid 1970s Yirrkala was facilitating a vibrant base for Indigenous artistic business, and in particular the emergence of prominent Indigenous female artisans, who today live in the remote outstations.

Mid 20 ${ }^{\text {th }}$ Century Onwards: By the 1970s there was considerable market opportunity for Indigenous small business in the Nhulunbuy region. When building the Gove airport in 1943 for military purposes high grade bauxite ore was found (Department of Defence, 1978; Pretty, n.d.), and by the late 1950s the extent of the deposits had been established leading to the formation of the Northern Australian Bauxite and Alumina Company (NABALCO) (Going for Gove, 2003). A formal agreement between NABALCO and the Australian Commonwealth Government was approved in 1968 and in that year a feasibility study for building an 800 tonne capacity mining/refining operation and the construction of the town site of Nhulunbuy was completed (The Gove Bauxite Development, 1968). By 1970 building the mining/refining complex, the town site of Nhulunbuy, and the auxiliary infrastructure was well advanced. To build this massive project a non Indigenous workforce flooded into the region with an enormous appetite for food and Indigenous artefacts.

The Yirrkala Art Centre, which opened in 1976, emerged from the closing of the Methodist mission health facility. By the late 1960s alcohol was readily available in Nhulunbuy and a high level of substance abuse had a devastating influence on the large Yirrkala Indigenous community. After an unsuccessful appeal to the Darwin Supreme Court to have the liquor license of the Walkabout Hotel revoked the Indigenous leaders led their clans back to their traditional homelands. Altman (2003) refers to this exodus as the outlands movement of the 1970s. Coupled with political change when the NT Government assumed responsibility for education and health (core functions of the missionaries) the missions became anachronisms and Yirrkala closed in 1975. The museum component opened in 1988 and today the Yirrkala Arts Centre provides an outlet for Indigenous art businesses from the 29 outland communities.

Electronic documents generated by anthropologists reveal early entrepreneurial endeavours by Indigenous Yolngu. Housed in the Yirrkala BukuLarrnggayMulka Art Centre is the 1971 black and white recording of Daymbalipi Munungurr of the Djapu clan, together with his nuclear and extended family, at Daliwuy Bay, $10 \mathrm{~km}$ from Yirrkala showing six Aboriginal women removing oysters from mangrove roots that had been collected earlier by use of a dingy at low tide (Dunlop, 1995). By the close of the morning four large hessian bags filled with oysters were loaded onto the back of an utility in preparation to be transported to restaurants at the Gove Airport tent city or the kitchens of the workforce accommodation units at Birrtjimi. A separate record reveals the master artist NarritjinMaymuru of the Manggalili clan established an art studio at Yirrkala in 1971 where he allowed women family members to paint for the contemporary world. The foresight of Narritjim and other prominent male artists (e.g., BakulanggayMarawili, Baniyala homeland; DulaNgurruwuthun, Rurrangala homeland; YanggarrinyWunungmurra, Gangan homeland) led to a wider spread of sacred and secular art by women, who as they became more skilled were allowed to embrace in their work the clan spiritual dimensions of existence. The emergence of female artists on the Gove Peninsula came at a time when the leading male artists were at the height of their careers allowing their sons and daughters to lead the centres of creativity in the small bush outstations (Brody, 2011).

Cottage craft of the remote outstations has emerged as the main small business of the Yolngu women. A great deal of the art of the Indigenous men (and women) is purchased by the Yirrkala BukularrnggayMulka Art Centre that has by clever marketing provided accessibility of the artworks and 
the authors to the national and international arena. Inspired by the exposure of Arnhem Land Indigenous women artists as prize winners of prestigious international awards other regional Yolngu women have independently invested in small business arrangements. Historically, Indigenous organisations on the Gove Peninsula have been undertaken in patriarchal contexts that have considerably restricted the prominence of female entrepreneurship. While these male dominated systems prevail the achievements of Indigenous women are beginning to be voiced in the local and wider community, and it is some of these women and their followers who are the target of this study.

\section{Methodology}

Site: The study was conducted on the Gove Peninsula. Within this region, which encompasses nearly $100,000 \mathrm{~km}^{2}$ of land owned by the Yolngu people, is the town site of Nhulunbuy. The town of Nhulunbuy is the third largest regional centre in the NT with a population of some 4000 people, mostly non Indigenous. On the Gove Peninsula over 4000 Indigenous people live in remote outland communities, and this study mainly targeted the closer Aboriginal communities of Birrtjimi, Galupa, Gunyangara, and Yirrkala as well as the more distant outstations of Bawaka, Dhalinybuy, Dhanaya, Gangan,Gilka,Gurrumura,and Yuduyudu.

Respondents: There were 21 Indigenous female entrepreneurs who provided primary data. Within these participants were a mother and a daughter who were the senior members of a remote family business. There were four master painters: one with interests in tourism; another with a yidaki enterprise; a third with a vision for an alternative health care business founded inlocal flora constituents; while the fourth added to her painting stream with carvings, weaving and jewellery. Two women street vendors, who were selling paintings in the Nhulunbuy shopping centre were included in the sample. The female manager and the four women drivers of the Nhulunbuy/Gunyangara/Yirrkala night patrol as well as the seven women and their supervisor, who were operating a horticulture nursery at Gunyangara, were separately interviewed. Until the 1980s senior men dominated Yolngu painting. Women (as daughters) were supervised and restricted in what they could paint in the clan dynasties of artists. While Yolngu women have been allowed to weave or make jewellery, and paint 'in the background', they are only allowed to paint on bark/canvas, carvings, the yidarki or coffin poles (larrakitj) and autonomously present the sacred designs of the clan estates when approved to so do by their Elders, or when they become the Elders of their family. Hence, the sample of painters lacks relatively young Indigenous women (i.e., aged above 50 years), while the ladies operating the night patrol service or the nursery were in the 30 to 40 years of age group.

Most of the women sample held formal Western education qualifications of recognised colleges. Also they were competent in the protocols of business compliance and regulations, and many had their own web sites. Consequently, these respondents were able to comprehensively articulate their views with the authors. The ladies, who operated the night patrol service held recognised qualifications, including a certification to operate a motor vehicle, which is a competency acquired by few Indigenous Yolngu. Although the women, who operated the nursery were extremely capable in the horticultural dimension of the business they had only been exposed to the NT bilingual education system and were English illiterate, and thus, confined to speaking their clan mother tongue in which the second author is fluent. Five men were invited to corroborate and enrich the information given by the women. Three prominent Elder Yolngu men (a master painter, an executive of the East Arnhem Shire, and a community leader) were provided forums to explain how indigenous females from the remote centres on the Gove Peninsula have created their cottage craft businesses. Opportunity was also given to tell how during the past 15 years other Indigenous women have operated small enterprises that make a valued social contribution to Nhulunbuy and the nearby communities of Galupa, Gunyangara and Yirrkala as well as the remote outland centres. The two male curators of the Yirrkala BukuLarrnggayMulka Art Centre and Museum, who are regularly involved with purchasing artistic products from the women (and men) who reside in the outland centres, and facilitate the promotion and accessibility of the artists and their work, were interviewed.

Measurement: The Indigenous women were asked to respond to two key questions.

- What are your motivations for wanting to operate a small business.

- What are the main barriers you have faced when trying to develop your ideas into real life ventures. The responses were recorded and evaluated by manual content analysis. 
Procedure: Primary data were obtained through interviews. Yolngu people are making “... a transition from an oral culture to a literate culture." (Kral 2009:1), and many are uncomfortable with written English, while those taught in remote communities usually only learn their mother tongue and have understated levels of spoken and written English. Hence, written responses were not sought. Long term relationships between the authors and the Yolngu community underpinned a strong research partnership. The second author has lived in Nhulunbuy for 14 years, has travelled extensively across the Gove Peninsula, is fluent in the local Indigenous mother tongue, and has been continuously visiting the remote communities in managerial duties for the regional Indigenous vocational educational training (VET) programme. Since 2007, the first author has regularly attended the Nhulunbuy region visiting Indigenous communities, speaking with Yolngu women and men leaders in a role of assisting and recording the VET scheme (Daff \& Pearson 2009; Pearson \& Daff, 2010; 2012). During this period high levels of community trust have been built with an opportunity to observe and undertake dialogue with the leading Yolngu women and men artists. A sustainable research programme was conducted over a period spanning six years with Gove Peninsula Indigenous artists as both authors have been accepted into kin based relationships with the Yolngu community.

A longitudinal study design has a practical feature. Indigenous Yolngu are transient occupiers within their traditional ancestral lands, as they may be attending ceremonies, cultural events or funerals (all of long duration up to three months) in other regions of the country. In the 'wet' season (October to April) road inaccessibility encourages homelands to be vacated when the people move to family homes within the safety of larger centres. Finally, seeking approval and obtaining a permit to visit a homeland has to be coordinated with the likelihood the respondents will be at their homeland residence. Collectively, these issues inhibit the employment of the orderly short term plans of set time and place engagements, and often interviews are convenient opportunity solicited over a long time period. Secondary data were obtained from written and electronic material. Available brochures, reports and other written documents of local Indigenous organisations, that were not included in the study reported observations, were examined. For instance, all of these companies had web sites, as did most of the firms that were chosen, and this material provided valuable information expressing Indigenous aspirations to manage enterprises in their country. Invaluable knowledge was obtained from the 18 DVD products (The Yirrkala Film Project) that were compiled by the renowned anthropologists who regularly visited the Gove Peninsula from 1970 to 1995.

\section{Results}

The respondents consistently reported their ventures, or future extensions to their business aspirations, were arrangements motivated by economic and social dimensions. All of the respondents commented either implicitly or explicitly, that they held visions to create a new economy within, but not inextricably melded to the dominant Australian market economy. In other words, while the business conforms to the appropriate governance mechanisms functioning of the business has to be integrated with customary cultural values and practices. For instance, reinvigoration of the customary Indigenous lifestyle of remote communities in the NT embraces wildlife harvesting, attending Indigenous cultural/religious events to learn the unwritten laws of the clans, and these activities are unlikely to be practiced in mainstream Australian small business. Executing these two disparate activities (i.e., financial management, cultural demands), while endeavouring to create a sustainable business, ultimately non reliant on continual government funding, exposes a range of implementation barriers.

Economic Motivators: Responses from the Indigenous women to the question, why they want to conduct a small business, were flavoured by linkages between economic and social elements. A representative comment from an artist was "Many remote Aboriginal communities are poor, few of the people have work, and many live on welfare so to improve living conditions people create art.".An Indigenous lady who works in the nursery gave a functional response. "I have a job. We get some money, each day we get three meals from the Community Development Employment Programme (CDEP) kitchen, and I can live.". The Indigenous female who was operating a tourism business stated the main aim was to create a new economy by sharing the family personal stories, culture and history. These replies demonstrate an instrumental monetary coupling with traditional society in emerging contexts of modernity. The economic dimension has manifested with consumer aspirations and market opportunity. Those Indigenous women, who have a desire to live on clan estates in hybrid economies (Altman, 2002; Pearson \& Helms, 2013) where cash has become increasingly important (Cook \&Monypenny, 2012), claimed by creating art businesses they could use the extra money "... to buy clothes, food and other things.". 
Intensifying artistic output in remote communities is fostered by the taxi fare from a remote settlement to Yirrkala ( $\$ 600$ to $\$ 800$ each way), which is met by selling large consignments to the Yirrkala Art Centre, and the surplus money is used to buy consumables from the two large Nhulunbuy stores. Confirmation was given by two Yolngu male Elders, and a prominent female Yolngu artist. One male respondent said. "Operating a small art business gives women more income for food, clothing and daily living as the men keep most or all of their money for themselves.". A second Yolngu man, who held a prominent position in the community, further elaborated with the comment. "Restrictions on money flows (Reframing CDEP), less paid work, the convenience of craft working in the homeland community and the opportunity to sell to the non Indigenous population has encouraged the development of female artistic businesses on the Gove Peninsula.". The overall thrust of the economic pursuit was provided by an Indigenous female master artist. "We want to be economically self sufficient. To win back our pride, we have to be less reliant on the government and its agencies.". In the lifestyle of the Yolngu people money is not viewed as future wealth, but as a functional daily asset.

Monetary gain was a secondary objective for the Indigenous women who drove the night patrol vehicles and those ladies who operated the nursery. The main aim of the night patrol service is to provide culturally appropriate assistance to Indigenous people (often suffering substance abuse) at risk of either causing harm or being harmed (Night Patrol Service, 2010). Women night patrol drivers receive annual training, are certified to drive a motor vehicle, and are employed at a casual pay rate. Conversations (independent) with these Indigenous women led to a conclusion they appreciated the financial payment, but it was less important than their maternal role. Often it was put "... we have extended our gender role of the 'clan gatherers' to remove the inebriated (often young men) from harm and take them to the sobering up shelter." The women who worked in the Gunyangara nursery provided at a range of reasons for working. A selection of the more frequent notions is listed.

- To get out of the house we want to work, but there wasn't many jobs, so I come to the nursery to look after the plants.

- With a job I can get off welfare.

- To have a job is a good feeling and I can buy some things for the family.

- Being here some (6) of us completed a Certificate 1 and a Certificate 2 in retailing, and we want to operate a local store as the taxi fare to Nhulunbuy shops is $\$ 60$ each way.

- We are working for ourselves.

These responses obtusely refer to the financial dimension, and the lack of its importance becomes evident in the later Cultural Barriers sub section.

Social Motivators: Respondents persistently promoted the social benefit as an objective for creating an Indigenous business on the Gove Peninsula. Acknowledging the importance of a sustainable economic platform the Indigenous ladies with tourism interests focussed on the kinship obligations and pressures. A representative comment was "... we can create a new economy across east Arnhem Land by employing our people in tourism, which will give a social dividend allowing the clans to stay connected with our land.". More directly related to the social benefit was the statement from a master female artist. "I do not do art to get rrupiya(money) or international awards. I want to be famous for my land and my children.". The encapsulated consistency for the social theme as perceived by the ladies who worked at the nursery was given in the words of one of them who said. "By working in the nursery we can remember of the need to care for the land, to maintain our cultural inheritance, and to build our community.". These notions were consolidated by an Elder Yolngu man who stated. "Indigenous women artists do not do it just for money in their pocket. Usually it is done by small families (e.g., mother and children) to tell the stories of the clan/family and to strengthen and preserve their community. In this way the children learn the culture and the skills. Besides men would not sell their paintings on the street as they would lose respect.".

A series of interviews that were undertaken with three Indigenous female artists revealed undertones of social themes. As these respondents were from different clans separate interviews were undertaken in respect of the deeper more sacred and secret expressions of relationships with creators, ancestors and the land in their work. Several engagements were necessary as on some occasions there was reluctance to talk about certain topics, but what was voiced was their artistic product attracts a variety of social factors. Their collective comments can be succinctly presented by paraphrasing the notions of their extensive responses. Through art (painting, jewellery, sculpturing, weaving) it is possible to depict the stories of the clan/family, which is represented with specific totems/symbols, using ochres from stones collected at the 
homeland. Thus, an artist's work has a copyright. The children learn the cultural heritage of the family (through art, song, and dance) and they are taught the skills by their parents, or when the fathers and mothers are deceased, by other family members. Sometimes the product is so sacred it is only for the immediate family while other versions of the illustrations are for everyday things in nature to offer a rewarding and memorial experience to the non Indigenous community. An overview of the social implications in the artwork industry that was generated by the women was given by a Yolngu Elder male who said, "Men are happy to train women to paint on bark (or canvas) as it is a traditional method of teaching people about their heritage through imagery to tell the times of creation. It is an exciting new dimension of Indigenous business to embrace the non Indigenous modern society." Table 1 presents a summary of the nominated motivators/drivers for creating a small business. The comments given by the Indigenous women were conveniently categorised as economic and social topics with the more often recorded attributes given at the top of the list. Focussing on aspirations required generating social capital within the family or community to achieve the targets may have been an outcome of responding to the first question in isolation to contextual factors.

Table 1: Motivators for Australian female Indigenous small business

\begin{tabular}{ll}
\hline Economic & Social \\
\hline Create a new economy & Cultural maintenance \\
Generate income & Create new family futures \\
To run a business & Children learning from older people \\
Economically self sufficient & Strengthen the community \\
To work for ourselves & Art to connect people and country \\
No reliance on government & Networking with non Indigenous Australians \\
Increase employment & Improving health, education and housing \\
\hline
\end{tabular}

Resource Based Barriers: Two categories of business barriers were identified by the respondents: resources and culture. Foremost of the resources was money to seed the venture with an imprecise caveat of "ganggamärr" (only a little)is required. Another prominent resource attribute was market identification, which attracted consideration of product durability and in turn the transportation requirements for goods and clients from and to isolated centres. A perception of the Indigenous women from the remote communities was "... we can sell our paintings, carvings, and jewellery to the Yirrkala Art Centre.". In contrast the ladies who worked in the Gunyangara nursery sold their product directly to those organisations that landscaped the Nhulunbuy precincts or to private householders.

Respondents outlined a range of resource impediments that were interwoven in the fabric of their lifestyle. For instance, obtaining artistic resources obliged family members to undertake consensual agreement for the abnormal activity of planning the collection day. One female artist said "... we have to get the best women workers, to organise a workable boat, and the fuel as we have to travel across Melville Bay to the Yuduyudu homeland to collect our materials.". Another lady artist told how deciding to do the sculpturing meant people (women) had to be organised and the work done quickly (as the wood hardens, splits, and warps), yet they still had to do their other family daily jobs. "The milk wood has to be cut and carved in a few days as it soon goes hard. We get a number of women together and sit under a bush shelter (we made) and do all the carving in a short time.". Another Indigenous lady told about the resource attributes of weaving. "We all go together and collect the pandanus fronds. Then we have to strip out the fibres that we dye with colours (red and brown) we get by boiling the roots of special bushes. Only those women with strong finger nails and long fingers can weave.". As the materials have to be obtained from ancestral homelands travelling can be problematic. It is common for Indigenous people to walk $15 \mathrm{~km}$ to $20 \mathrm{~km}$, while longer distances of travel in a reasonable time in the dry season requires a suitable vehicle that attracts monetary payment or the good will of a family member who is rewarded in the framework of obligatory gift giving in the clan.

The importance of environmental issues was noted as the extreme cyclic weather conditions of the NT (wet and dry) can adversely affect business continuity. For example, in the wet season (November to April) road inaccessibility is inevitable, dangerous health hazard arise (e.g., box jelly fish, melioidosis), and temperature extremes become unattractive for tourism, which can significantly impede small business activities. Compliance to appropriate governance mechanisms attracted fewer comments, which is indicative of the notion prudential financial management being misunderstood or it is overridden by community social priorities promoting block funding (no constraints on use) as a preferred available alternative. A lack of economic opportunity and restricted self determination are impediments to 
Indigenous female entrepreneurship. Despite government efforts to provide fundamental skill training in management and organisational governance, to prepare applicants for fulfilling the Indigenous Business Development Programme (Australian Government, 2007) requirements (e.g., complete forms, application fee, demonstrate commercial acumen), sustainable Indigenous business is precarious (Cook \&Monypenny, 2012; Furneaux\& Brown, 2008; Russell-Mundine, 2007). Yolngu identity is grounded in family and kinship obligations, land affiliation and clan languages that are factors very different to Western notions of individualism, business control, firm accountability and regular financial reporting. Arguably, core government frameworks for facilitating Indigenous small business with one size fits all top down strategies might benefit by accounting the diversity of remote Indigenous communities. This point was made by an Indigenous lady who was endeavouring to establish a tourism venture.

'They [the government] send people here with a lot of forms for us to complete. They tell us how to live our lives and how to run our business on our land. They do not seem to care about our obligations for family, the expectations of blood kin, and other important social responsibilities such as child minding, sharing to preserving the community and helping family members. Many of the ladies in our community have never worked. These women have to learn about regularity of work days and hours, sitting at a desk, and doing jobs. Some of them do not want to work. These problems do not appear to be important to the government officials.".

Closing the divide between the strong attachment to the traditional Indigenous way of life and the government ideals of Western enterprise problems might be better facilitated by collaborative policy development.

Cultural Barriers: A number of the perceived barriers to entrepreneurship were embedded in cultural values and practices. Prominent were network problems linked to nuclear family and extended family members who have expectations of sharing business proceeds, yet the recipients may not invest in operating the business. While social prestige is accrued by the giver, the distribution of wealth in this kinship system detrimentally impacts business sustainability. Further, the production losses or disruption to business continuity occurs with obligation to attend festivals, funerals or 'sorry days'. Resource sharing (e.g., land) in remote NT Indigenous communities embraces economic and social interactions influenced by the status and power of the stakeholders, which can impede business advancement until the long term cultural sensitivities are resolved. Overall, comments from the Indigenous ladies demonstrate they operate in an elusive and complex non homogenous context considerably different to the dominant mainstream Australian small business framework. A summary of the obstacles to Australian Indigenous female entrepreneurship that were nominated by the respondents is given as Table 2 .

\section{Table 2: Barriers to entrepreneurial development}

\begin{tabular}{ll}
\hline Resources & Cultural \\
\hline Money & Family nuclear and extended \\
Market and transport & Hierarchical position power and asset possession \\
Client/customer & Social order kinship \\
Environmental periodic weather and effects & Festivals funerals sorry days \\
Business acumen/compliance & Property ownership clan/family demarcation \\
\hline
\end{tabular}

Yolngu women engaged in small ventures experience conflict in competing aspects of Western business operating requirements and Indigenous cultural protocols. On the one hand if their operations are to produce sustainable results and contribute to community good there is obligation for asset capitalism within conditions of transparency to regulatory requirements and practices of governance. On the other hand providing for immediate and extended family, many of whom are likely to be gift recipients, and not contributors to task activities within the business, are distinctive cultural imperatives enmeshed in detrimental forces for community business. The success of the female Yolngu business was determined by how these women were able to blend the commercial and social priorities. An absence of separation between working and cultural forces was described by a number of Indigenous women and summarised by one Yolngu lady, who worked at the nursery.

"They humbug me. Ask me for money and become violent when I do not give them things. Most of us ladies who work at the nursery are trying to improve ourselves. Some of the community just want to take from those who do have a job and money and things. Women are under the control of men. What can we do?". 
The stresses and strains imposed on the Yolngu women were often accommodated by them withdrawing from the work scene and becoming a taker from the more resilient females who continued to work.

Resilience also has cultural connotations. During visits to the residence of a blood sister of the clan leader the interviewers were always impressed by the relatively immaculate grounds and a well kept motor vehicle in the driveway, yet surrounding houses had unkept grounds, often held wrecked or damaged vehicles and frequently there were a number of males in or around the houses. When questioned why the scenes were so different as well as how and why she was able to conduct an artistic business and be insulated from perceived threats of her surroundings the answer was forthright. "No men come here. I chase them away with a stick. My house has a reputation of being a safe house for women. We have a shelter in the yard under which we ladies do our painting, weaving, sculpturing and bead work in peace.". Clearly, her family connection in the clan and that she was a widow ensured "... violence which is central to and pervasive in Australian Aboriginal life." (Johns, 2011: 103) would be administered by the clan hierarchy for those who interfered with the cultural bonding between the ladies and the protection given by the clan leader. At the heart of Yolngu society are gender protocols and rituals that are inhibitors of Indigenous female business intensity. Only men can make and play the yidaki, while women can be allowed to paint the musical instrument. One renowned female Indigenous widowed artist has been able to uniquely integrate these cultural issues to build a successful business.

"In our [Yolngu] world, which is experiencing dramatic social change it has been possible for me to have my brother Djalu (an acknowledged yidakiplayer) play at national and international venues, sell our CDs of the music and with other family members conduct a profitable business from Birritjimi and our Gikal homeland."

Cultural norms provide a varying array of gender entrepreneurial activity. Both Indigenous men and women (when allowed) do sculpturing and the painting of the carvings, but only women weave the pandanus palm fronds, make bracelets or armlets and boil special roots to make dyes for the woven products. An additional gender attribute was highlighted by an Indigenous lady who stated, "The best women weavers have strong finger nails and long fingers.". Interpreting these and like comments demonstrate a regard for different cultural contexts that may inhibit or assist Indigenous female business development. Contemporary female enterprises are dominated by patriarchal systems. Earlier it was recounted intricate spatial relationships of tribal or clan affiliations define pathways for Indigenous Yolngu women to operate self owned business. These natural phenomena are known by all Yolngu individuals and when unrestricted may be the motivational pathway to create a small enterprise. One Indigenous lady artist outlined how the influence of family males had manifested to realise her motives.

"I get bored from minding other people's babies. I wanted something else and I saw other women stepping up. My husband had died and I was now the eldest in my family. I had been taught how to paint by my father, I knew the meanings of my clan designs and the facets of protocol restrictions so I began to paint. With the extra money I can buy clothes and food for my grandchildren. As the leader of my family I am allowed to tell the world of my family history with my own unique miny'tjisignature.".

Discussion: Exploring the drivers for establishing a small business exposed the lesser importance of financial capital and the greater relevance of culture. Often financial capital has been identified to be a principal factor for starting Indigenous entrepreneurship (Australian Government, 2009; Furneaux \& Brown, 2008; Russell-Mundine, 2007), while earlier Foley (2003) wrote "... money has little motivation to the Indigenous entrepreneur..." (p.137). The confliction in these viewpoints might be attributable to demographic differences (e.g., male versus female entrepreneurs) or contextual properties (i.e., suburban/urban versus regional settings). A reasonable blending of the two streams of contentions was provided by McDonnell (1999), who investigated Indigenous women entrepreneurs in the Torres Strait, and identified a lack of access to credit inhibited successful business activity. This observation led to the suggestion that alternative culturally relevant models for credit acquisition were warranted. The Indigenous women of this study expressed they were motivated to establish their businesses separate from, but attached to the Australian mainstream consumer driven society. Adopting this paradigm enables retention of cultural identity in an alternative framework to the colonial policy of assimilation, that denied Indigenous people the same opportunities as other Australians (Hughes \&Warin, 2005; Kaplan-Myrth, 2005), and the sea change to self determination that has not bettered outcomes for Aboriginal people . 
Through narration the respondents were able to communicate they engaged in entrepreneurship to create a new economy. There is strong likelihood that living in intergenerational over crowded houses, having considerable lesser quality available accommodation and of poorer hygienic conditions than most Australian suburban houses would be the genesis for a better lifestyle. Johns (2011) has suggested that Integration, which is a social and economic process that sits between the Australian government Indigenous policies of assimilation and self determination is a more suitable arrangement for Australian Aborigines. But a more embracing framework that accounts for cultural sensitivities and the discernible variances between urban and regional Aboriginal people attracts investment. Typical Indigenous entrepreneurship on the Gove Peninsula demonstrates the substantial relevance of culture. Business activity is often suspended by the strong stimulant to provide for the family (Foley, 2006) when families engage in hunter gatherer pursuits. Cultural protocols are exercised as the women collecting flora (i.e., fruits, nuts, yams), and the men hunting the fauna (i.e., crabs, birds, fish). By working together and sharing the catch that is consumed in a relatively short time (a custom imposed by the absence of refrigeration), families are able to use traditional skills and build social capital. A contemporary feature of entrepreneurship on the Gove Peninsula provides employment opportunities, and thus, creates pathways to transition to the mainstream society. For instance: weaving materials; bark for paintings; and the rocks for preparing the black, brown, and red ochres as well as the white clay for the fine line details on the art work has to be obtained from family lands, that may be a considerable distance from the remote community where the Indigenous women entrepreneurs live. These women are often reliant on men to drive them to the places where they can gather their art materials and the men can strip the bark from trees with axes and traditional peeling sticks. Thus, work opportunities are created for men as well as a variety of jobs auxiliary to operating the vehicle. The women are a distinct entity practicing family, religious and cultural protocols, but they are also modifying their Indigenous values to adjust to the contemporary mainstream economy, collectively requiring them to address the phenomenon of crossvergence.

Crosssvergence is a debatable construct in the international management literature. Coined by Ralston and colleagues (1993) crossvergence is described as an unique set of institutional rules, behaviours and values that originate from the amalgamation of divergence and convergence forces. In the context of the Indigenous female entrepreneurs, who are embedded in their Dreamtime, which is a wholistic spiritual view of the world, and the clan laws of the Madayin, these women are impacted by divergent forces. But they are also pressured to conform to the business compliance regulations, the taxation requirements, and etiquette of the dominant mainstream economic practices. These elements, which are foreign to the fabric of traditional Indigenous lifestyle, are the convergent forces. The female Indigenous entrepreneurs on the Gove Peninsula are challenged to find a fine balance between deep rooted tradition and modernity, which is the crossvergence pathway.

An operating example of the entrepreneurial barrier of crossvergence is the community patrol service in the Nhulunbuy region. Each night three yellow vans, similar to police division vans, are driven in the town of Nhulunbuy and the Indigenous communities of Birrtjimi, Galupa, Gunyangara and Yirrkala by Indigenous women to provide culturally appropriate intervention for inebriated Indigenous people. These intoxicated people, who are at risk of suffering or causing harm in the community, are taken to the Nhulunbuy Special Care Centre. Initially, this small enterprise was conceived by local Indigenous women from Gunyangara and Yirrkala aiming to place Indigenous people affected by substance abuse (alcohol, drugs, sniffing volatile substances) into safe 'sobering up' shelters. A rudimentary service was commenced in 2005, when the mining company Alcan provided a vehicle, and a rehabilitation unit was built. Today there are three vehicles, there is an extensive residential rehabilitation centre in Nhulunbuy, there is an Indigenous lady manager who coordinates the service from the East Arnhem Shire Council in Nhulunbuy, the women drivers are accompanied by a burly Indigenous man to provide 'muscle', and the service is funded by the Australia Government Attorney-General's Department (Night Patrol Services, 2010). Indigenous women drivers can be rostered from a pool, which ensures a continuity of service while other women can be absent to attend festivals, funerals or cultural events. The Indigenous ladies are able to conduct their inaugural vision of delivering culturally appropriate support services to Indigenous people at risk, yet be somewhat isolated from parts of the system (e.g., economic arrangements, overall guiding principles, rehabilitation), but connected with the wider community, which are the primary exhibitors of crossvergence.

In the stories narrated by the Indigenous ladies a number of entrepreneurial barriers were identified. Money has been mentioned previously. Many other obstacles had elements of cultural values and 
practices, and of prominence were those based on kinship (blood line connections) that arise in the expectations held by the members of the nuclear and the extended family. Paradoxically, kinship is the reason for the members being together, and it provides the blinding forces that are the foundation of social capital vital for building trust and allocating meagre available resources in remote communities, yet these same forces can shatter the sustainability of the business. A recurring message given by the Indigenous women was the contributions of family members were frequently greatly exceeded by the withdrawals (goods, money, assets), but these inequalities had to be met as this was part of the process of providing for the family in an obligatory gift giving society. A salient inference to be drawn from the responses is the female Indigenous entrepreneurs displayed cognition and motivation to outweigh family imposed sanctions that hampered business profitability.

Recent research has nominated a variety of barriers to contemporary small business. Lutz, Kemp and Dijkstra (2010) provided an overview of strategic and structural barriers facing entrepreneurs in the modern economy. Although their findings were not specific to Australian Indigenous small business some of their observations overlapped an earlier presentation by Russell-Mindine (2007) who listed barriers to enterprise development perceived by Indigenous Australians. Except for the relevant cultural barriers there was scant correlation between these two literature sources and the responses of the female entrepreneurs of this study. For instance, land was not a barrier as east Arnhem Land is native titled and clan members are aware of their holdings. Nevertheless, land can become a barrier if one clan wants land access via another clan's holding. Distance to market has been recognised as an impediment to venturing, but the women have developed strategies to sell their products in the local larger centres of Nhulunbuy and Yirrkala. And even education was not seen as a barrier to the senior Indigenous lady respondents. They had been educated in Australian capitals such as Darwin or Brisbane, these women were seasoned international travellers often with their own websites, and they were articulate in the present day electronic technologies.

The respondents perceived gaps between their current and future circumstances. One respondent had a vision to extend the tourism precinct by building a number of cabins, but the identified resource was an English illiterate Indigenous man who had worked at a forest timber mill. Another Indigenous lady continues to hold a belief her business could be expanded to have an alternative bush medicines clinic using local flora. A vision for a remote community to catch and selfish from a nearby river is yet to excite the people to begin the project. Although this 'open' policy of apparent meandering toward a target may not sit well with contemporary business planners and strategists the non strategic philosophy adopted by the Indigenous females has a gifted heritage. From ancient Indian contexts a well preserved statement still abounds; It will be all right in the end, and if we are not yet there, trust me, as it is not yet the end. While the responses revealed there are inhibitors to business ideals and growth the capacity for opportunity was also demonstrated. While it might appear to the uninformed viewer the entrepreneurial Indigenous women are muddling through, in a relatively short time a number of them are achieving some success on the Gove Peninsula.

Australian Aboriginal art distinctively contributes to the global market and commercial opportunity in limited domains. In spite of considerable investment through Commonwealth, government policy initiatives and funding programmes many Indigenous communities continue to experience profound levels of social and economic marginalisation, and in particular Australian Aboriginal art has yet to substantially penetrate the international markets. Contrasting this landscape the evidence presented is that a number of Yolngu female artists have developed creative art related industries in their remote homeland communities, and now their work is accessible to domestic and international markets through the Yirrkala BukularrnggayMulka Art Centre. This achievement has far reaching implications for a range of stakeholders. The immediate and extended families of these artists are able to acquire a spread of tangible goods, and improve their life styles, while the agency of the Yirrkala Art/Museum Centre is financially commissioned to deliver a great variety of clan designs that mark the identity of people and place. On a wider and more intrusive platform those employees and entrepreneurs actively associated with promoting Aboriginal art to collectors, galleries, and exhibitions locally and internationally, who are the privileged curators and coordinators entrusted to share the wonderful array of sacred designs that are at the heart of Yolngu society. 


\section{Conclusion}

This study was conducted with female Indigenous entrepreneurs in a distinct form of small business. Today the respondents are nested in a patriarchal clan structure and bounded to social arrangements with obligatory norms that give the women their cultural identity. Despite business interactions with seafarers for over three hundred years, some fifty years of missionary influence, the bleakness of colonial process segregating Indigenous Australians and curtailing their entrepreneurial opportunity, together with the Australian policy of self determination, the permanency of the complex social interconnectedness of the Yolngu clans is a dominant thread of their daily living. These observations provide a seldom reported perspective in Australian Indigenous female entrepreneurship. A feature of this study is the giving of voice to a marginalised group of respondents. The authors have coalesced narrations of the Indigenous ladies over a reasonable period necessary to generate trust and climates of openness. English is not the first language of the respondents and may not even be the second or third set of auditory symbols, and in some instances the second author had to interpret non English words. Readers will have to judge the extent of the limitations of the employed methodology. The characteristic criticisms of a small sample precluding data testing with standard statistical procedures, and the collecting of oral responses unlinked to written statements can be expected. Nevertheless, an ethnographic methodology for capturing the expectations and experiences of Indigenous women entrepreneurs with their words is a robust procedure given that their context has virtually remained unchanged over many centuries. Later researchers might consider investigating other remote inaccessible regions of the NT to record the extent of creativity, innovation and enthusiasm for entrepreneurship by the resident Indigenous women.

The findings of this study do not resonate well with other relevant published material. For instance, in spite of their marginality in the dominant Australian culture the respondents were self confident, never were the primary reasons for embarking on entrepreneurial pathways aligned with reasons given in the mainstream literature (i.e., to escape poverty, to earn investment income), but rather maternalistic priorities, dominated by actions to provide for the family. Hence, adherence to the economic priorities espoused by Australian government representatives and departments responsible for the euphemism of the federal government's commitment to small business development was discounted by the female entrepreneurs. These findings provide a strong message for institutions anchoring institutional processes and the contemporary technologies in work settings within the contextuality of remote Australian Indigenous communities.

The theoretical typology of the notion of entrepreneurship outlined in this paper does not closely aligned with the established theories. Overtime, interest in the creation of a new business has spawned endeavours to construct definitions of entrepreneurship. The more popular views are entrepreneurship as the driving force for wealth creation, the activity is founded in innovation and knowledge creation trigged by research and development, and is facilitated by institutional frameworks to deliver a product and/or service to a contemporary marketplace. Although these propositions are likely to resonate in metropolitan and urban contexts, only the last item found traction in the entrepreneurship exercised by the female Indigenous respondents on the Gove Peninsula. Studies on entrepreneurial activities in remote regions have led to suggestion in these environments entrepreneurship is less about perceived opportunity and more about a function of the cultural perception of an opportunity; a viewpoint within the wider rationality espoused by the female study respondents. Clearly, the evidence presented in this paper does not fit well with the existing models of entrepreneurship confirming a foundation for further academic research to better understand the forces of operating in the female Indigenous business activities in remote regions.

\section{References}

Abbott, T. (2002). Grass roots capitalism. Retrieved from http://www.tonyabbott.com.au/speech/grassroots.html

Altman, J. C. (2002). Indigenous hunter-gatherers in the $21^{\text {st }}$ century: Beyond the limits of universalism in Australian social policy?. In T. Eardley and B.Bradbury (Eds), Competing visions: Refereed proceedings of the National Social Policy Conference 2001, SPRC Report 1/02 (pp. 35-44). Sydney, University of New South Wales: Social Policy Research Centre.

Altman, J. C. (2003). People on country, healthy landscapes and sustainable Indigenous economic futures: The Arnhem Land case. The Drawing Board: An Australian Review of Public Affairs, 4(2), 65-82. 
Australian Government. (2007). Indigenous programs: Business and employment. Retrieved fromhttp://www.oeeo.wa.gov.au/documents/diversitybizz/past\%20articles/Indigenous\%20pr ograms $\% 20$ Business $\% 20$ employment.pdf

Australian Government. (2009). Indigenous small business owners in Australia. Canberra: Australian Taxation Office.

Australian Government. (2010). Indigenous economic development strategy: Draft for consideration and action plan 2010-2012.Canberra:Australian Government Printer.

Australian Women Chamber of Commerce and Industry (AWCCI). (2012). Collection of sex desegregated data and the procurement of contracts for women business owners in Australia. www.awcci.org.au

Berndt, R. M. \& Berndt, C. H. (1999).The world of the first Australians: Aboriginal life past and present. Canberra: Aboriginal Studies Press.

Brody, A. M. (2011). Larrakitj: Kerry Stokes collection. West Perth, W.A.: Australian Capital Equity.

Cape York Indigenous Employment Strategy. (2005). Local jobs for local people. DEWR, Canberra:Kleinhardt - FGI/ Business Mapping Solutions.

Choi, H. C. \& Sirakaya, E. (2006).Sustainability indicators for managing community tourism. Tourism Management, 27(6), 1224-1289.

Cook, J. S. \& Monypenny, R. (2012). Self-management of remote community organisations: Getting nowhere no-time soon. Journal of Australian Indigenous Issues, 15(3), 2-17.

Daff, S. \& Pearson, C. A. L. (2009). Indigenous employment: The Rio Tinto Alcan initiative in northern Australia. Contemporary Issues in Business and Government, 15(1), 1-20.

Dana, L. P. (1995). Entrepreneurship in a remote sub-artic community. Entrepreneurship Theory and Practice, 20(1), 57-72.

Department of Defence. (1978). Letter outlining different military units involved with construction of the Gove Airport. Nhulunbuy: Held in Special Collection Nhulunbuy Community Library.

Dunlop, I. (1995). This is my thinking Daymbalipu Munungurr DVD 52 Minutes. Pymont, New South Wales: The Yirrkala Film Project Film Australia National Interest.

Foley, D. (2003). An examination of Indigenous Australian entrepreneurs. Journal of Developmental Entrepreneurship, 8(2), 133-151.

Foley, D. (2006). Indigenous Australian entrepreneurs: Not all community organisations, not all in the outback. Canberra: Centre for Aboriginal Economic Policy Research, The Australian National University.

Furneaux, C. W. \& Brown, K. A. (2008).Australian Indigenous entrepreneurship: A capital - based view. Entrepreneurship and Innovation, 9(2), 133-144.

Going for Gove. (2003). Investment, interdependence and integration: Discussion paper. Canberra: Commonwealth of Australia.

Hindle, K. \& Moroz, P. (2009). Indigenous entrepreneurship as a research field: Developing a definitional framework from the emerging canon. International Entrepreneurship Management Journal. Retrieved from http://dx.doi.org/10.1007/s11365-009-0111-x

Hughes, H. \& Warin, J. (2005). A new deal for Aborigines and Torres Strait Islanders in remote communities. Issues Analysis, 54. Retrieved from www.cis.org.au

Hunter, B. H. (2012). Recent growth in Indigenous self-employment and entrepreneurs. Australian National University Canberra: Centre for Aboriginal Economic Policy Research.

Indigenous Opportunities Policy (IOP). (2011). The Indigenous opportunities policy. Canberra: Australian Government Department of Education, Employment and Workplace Relations.

Ivory, B. (1999). Enterprise development: A model for Aboriginal entrepreneurs. South Pacific Journal of Psychology, 11(2), 62-71.

Johns, G. (2011). Aboriginal self-determination: The whiteman'sdream. Ballan, Victoria: Connorcourt.

Jones, M. (2007).Unpacking social enterprise: A discussion paper presenting an Australian perspective. Forum held in Sydney 14th August, 2007 at Customs House, Circular Quay.

Kaplan-Myrth, N. (2005). Sorry mates: Reconciliation and self-determination in Australian Aboriginal health. Human Rights Review, 6(4), 69-83.

Kilpatrick, S., Field, J. \& Falk, I. (2003). Social capital: An analytical tool for exploring lifelong learning and community development. British Educational Research Journal, 29(3), 418-433.

Kukoc, K. \& Regan, D. (2008).Measuring entrepreneurship. Economic Roundup, 3, 15-26. Retrieved from http://www.treasury.gov.au/documents/1352/PDF/02_Entrepreneurship.pdf

Kral, I. (2009).The literacy question in remote Indigenous Australia. Canberra: Centre for Aboriginal Economic Policy Research, The Australian National University. 
Lutz, C. H. M., Kemp, R. G. M. \& Dijkstra, S. G. (2010).Perceptions regarding strategic and structural entry barriers. Small Business Economics, 25, 19-35.

MacKnight, C. C. (1972). Macassans and Aborigines. Oceania, XLII, 283-319.

MacKnight, C. C. (1976). The Voyaga to Maregé: Macassan Trepangers in Northern Australia. Melbourne: University Press.

McDonnell, S. (1999).Women business: Access to credit for Indigenous women entrepreneurs within Torres Strait. Canberra: Centre for Aboriginal Economic Policy Research,The Australian National University.

McKenzie, M. (1976). Mission to Arnhem Land. Hong Kong: Rigby.

Minifie, J. (2014). The silver lining: Cloud computing and small and medium enterprises. Carlton, Victoria, Australia: Grattan Institute.

Muir, S. (2011). Australian alternative spiritualties and a feeling for land. The Australian Journal of Anthropology, 22(3), 370-387.

Night Patrol Services. (2010). Night patrol services in the Northern Territory operational framework. Canberra: Australian Government Attorney-General's Department.

OECD. (1998).Women entrepreneurs in small and medium enterprise. Paris: OECD.

OECD. (2001).Women entrepreneurs in SMEs: Realising the benefits of globalisation and the knowledgebased economy. Paris: OECD.

OECD. (2012). Entrepreneurship at a glance: Women and entrepreneurship. Retrieved fromhttp://www.oecd.org/std/entrepreneurshipandbusinessstatistics/50537806.pdf

Pearce, S. (2011).Indigenous women entrepreneurs and the secret of success. Retrieved from http://newsroom.uts.edu.au/news/2011/11/indigenous-women-entrepreneurs-and-thesuccess

Pearson, C. A. L. \& Daff, S. (2010). Education and employment issues for indigenous Australians in remote regions: A case study of a mining company initiative. Journal of Human Values, 16(1), 21-35.

Pearson, C. A. L. \& Daff, S. (2012). Transcending hunter gatherer pursuits while balancing customary cultural ideals with market forces of advanced western societies: Extending the traditional boundaries of Indigenous Yolngu people of the Northern Territory of Australia. International Journal of Cultural Studies, 16(2), 189-208.

Pearson, C. A. L., Daff, S. \& Helms, K. (2014). Indigenous Australians overcoming vulnerability of employability by creating a viable labour market for local challenges. Global Journal of Human Social Science, 14(2), 1-10.

Pearson, C. A. L. \& Helms, K. (2012). A hybrid social governance Indigenous entrepreneurship model for sustainable development: The Gumatj clan innovation. Journal of Australian Indigenous Issues, 15(1), 76-94.

Pearson, C. A. L. \& Helms, K. (2013).Indigenous social entrepreneurship: The Gumatj Clan enterprise in East Arnhem Land. The Journal of Entrepreneurship, 22(1), 43-70.

Peredo, A. M. \& Chrisman, J. J. (2006).Toward a theory of community-based enterprise. Academy of Management Journal, 31(2), 309-328.

Pretty, W. (n.d.). Eldo and after.Nhulunbuy: Typed report held in the Special Collection Nhulunbuy Community Library.

Ralston, D. A., Gustafson, D. J., Cheung, F. M. \& Terpsta, R. H. (1993). Differences in managerial values: a study of U.S., Hong Kong and PRC managers. Journal of International Business Studies, 10(1), 249275.

Rose, F. G. G. (1987).The traditional mode of production of the Australian Aborigines.Sydney:Angus and Robertson.

Russell, D. (2004). Aboriginal-Makassan interactions in the eighteenth and nineteenth centuries in northern Australia and contemporary sea rights claims. Australian Aboriginal Studies, 1, 3-17.

Russell - Mundine, G. (2007). Key factors for the successful development of Australian Indigenous entrepreneurship. Tourism: Preliminary Communication, 55(4), 417-429.

Sarfaraz, L. \& Faghih, N. (2011). Women's entrepreneurship in Iran: A GEM based-data evidence. Journal of Global Entrepreneurship Research, 1(1), 45-57.

Searcy, A. (1909). In Australian tropics. London: Flood and Field.

Shepherdson, E. (1981). Half a century in Arnhem Land. Torrens Park, South Australia: Pan Print.

Sonfield, M. C. \& Lussier, R. N. (2009). Gender in family business ownership and management: A six country analysis. International Journal of Gender and Entrepreneurship, 1(2), 96-117.

Suter, K. (2003). Australia-one land: Two peoples. Contemporary Review, 283(1651), 84-90.

The Gove Bauxite Development. (1968). Feasibility report - supporting Volume VI.Sydney and Zurich Town: Nabalco Pty Ltd. 
Trudgen, R. (2000).Why warriors lie down and die. Darwin: Aboriginal Resource and Development Services Inc..

Whitford, M. M. \& Ruhanen, L. M. (2010). Australian Indigenous tourism policy: Practical and sustainable policies? Journal of Sustainable Tourism, 18(4), 475-496.

Wood, F. Q. (2011). Entrepreneurship in Australia: The missing links. Retrieved fromhttp://ussc.edu.au/s/media/docs/publications/Wood_ussc_report_Sept_2011.pdf

Wood, G. J. \& Davidson, M. J. (2011). A review of male and female indigenous entrepreneurs: Disadvantaged post - promising future? Gender in Management: An International Journal, 26(4), 311-326.

Worsley, P. M. (1955). Early Asian contact with Australia. Past and Present, 7, 1-11.

Yunus, M. (2006). Social business entrepreneurs are the solution. In A.Nicholls(Ed), Social entrepreneurship: New models of social change(pp. 39-44). Oxford, United Kingdom: Oxford University Press. 